\title{
Efektivitas Kitosan Dari Limbah KulitUdang Terhadap Angiogenesis dalam Penyembuhan Luka Eksisi pada Tikus Putih (Rattus norvegicus) Jantan
}

\author{
Effectiveness of Shrimp Skin Waste Chitosan Against Angiogenesis in \\ Healing Excision Wounds among Male White Rats (Rattus norvegicus)
}

\section{Efin Windi Dayanti ${ }^{*}$, Arimbi ${ }^{2}$, Maya Nurwartanti Yunita ${ }^{2}$, Hani Plumeriastuti², M. Thohawi Elziyad Purnama ${ }^{3}$, Prima Ayu Wibawati ${ }^{4}$}

\author{
${ }^{1}$ Bachelor of Veterinary Medicine, \\ 2Department of Veterinary Pathology, \\ ${ }^{3}$ Department of Veterinary Anatomy, \\ ${ }^{4}$ Department of Veterinary Public Health, \\ Faculty of Veterinary Medicine, Universitas Airlangga, \\ Kampus C Unair Mulyorejo, Surabaya, Jawa Timur, Indonesia, 60115 \\ Telp. (031)5993016, Fax. (031)5993015 \\ *E-mail : efin.windi.dayanti-2015@fkh.unair.ac.id
}

\begin{abstract}
ABSTRAK
Luka eksisi adalah luka yang disebabkan akibat terpotongnya jaringan oleh benda yang tajam. Kitosan mampu sebagai zat dalam penyembuhan luka salah satunya dalam proses angiogenesis. Tujuan penelitian ini yaitu untuk mengetahui efektivitas salep kitosan dari limbah kulit udang terhadap angiogenesis dalam penyembuhan luka eksisi pada tikus putih jantan. Sebanyak dua puluh ekor tikus putih (Rattus norvegicus) jantan dibagi ke dalam lima kelompok perlakuan yaitu $\mathrm{K}+$ luka eksisi dengan pemberian povidone iodine, K- luka eksisi dengan pemberian salep tanpa kitosan, P1 luka eksisi dengan pemberian salep kitosan 1,5\%, P2 luka eksisi dengan pemberian salep kitosan 2,5\% dan P3 luka eksisi dengan pemberian salepkitosan 5\%. Terapi diberikan sehari sekali selama tujuh hari. Hasil data rata-rata jumlah pembuluh darah baru dianalisis dengan uji Anova yang menunjukkan adanya perbedaan yang signifikan $(p<0,05)$ dan dilanjutkan dengan uji LSD (Least Significant Differences). Kelompok P1 dan P2 tidak memiliki perbedaan yang nyata, tetapi berbeda nyata dengan kelompok $\mathrm{K}+$, $\mathrm{K}$ - dan P3. Kesimpulan dari penelitian ini kitosan efektif dalam meningkatkan jumlah pembuluh darah baru pada proses penyembuhan luka eksisi.
\end{abstract}

Kata Kunci: angiogenesis, kitosan, pembuluh darah baru, penyembuhan luka 


\begin{abstract}
Excision wound is caused by sharp objects cutting the tissues. Chitosan is capable of being a substance in wound healing, that is in the process of angiogenesis. The objective of this study is to determine the effectiveness of chitosan ointment made of shrimp skin waste against angiogenesis in healing excision wounds among male white rats. Twenty male white rats were divided into five treatment groups, namely $\mathrm{K}+$ excision wounds with povidone iodine, $\mathrm{K}$ - excision wounds with ointment without chitosan, P1 excision wound with $1.5 \%$ chitosan ointment, P2 wound excision with $2.5 \%$ chitosan ointment and P3 wound excision with $5 \%$ chitosan ointment. Therapy was administered once a day for seven days. The results of the average data on the number of new blood vessels were analyzed using Anova test which showed a significant difference $(p<0.05)$ and then analyzed using LSD (Least Significant Differences) test. P1 and P2 groups did not show significant differences, but were significantly different from $\mathrm{K}+, \mathrm{K}-$ and P3 groups. From the results, it can be concluded that chitosan is effective in increasing the number of new blood vessels in the excision wound healing process.
\end{abstract}

Keyword: angiogenesis, chitosan, excision wounds, new blood vessels

\section{PENDAHULUAN}

Kitosan adalah turunan dari kitin yang merupakan hasil dari limbah atau produk samping dari pabrik perikanan, kitosan dapat diperoleh melalui reaksi demineralisasi dan deproteinasi yang kemudian ditransformasikan dengan reaksi deasetilasi (Dompeipen, dkk., 2016). Manfaat kitosan pada bidang kesehatan dapat digunakan sebagai antiobesitas, antikanker, antibakteri dan penyembuh luka (Wardono, dkk., 2012). Kitosan yang digunakan secara topikal pada luka dapat menginduksi migrasi sel radang, meningkatkan proses angiogenesis untuk regenerasi jaringan, meminimalisir luka, memperkuat jaringan baru dan melawan infeksi (Tekelioglu dkk., 2017).

Luka merupakan kerusakan yang dapat menyebabkan perubahan integritas epitel kulit, juga diartikan sebagai terputusnya suatu kesatuan struktur anatomi dari jaringan yang dapat disebabkan oleh trauma maupun kerusakan sebagian jaringan tubuh (Sastrawan, dkk., 2016). Penanganan luka secara tepat sangat dibutuhkan agar penyembuhan luka berjalan dengan tepat dan tidak menimbulkan komplikasi lebih lanjut (Rairisti, 2014). ). Luka dapat diklasifikasikan menjadi luka terbuka atau eksisi dan luka tertutup atau insisi (Arun, et al., 2013). Luka eksisi adalah luka yang disebabkan akibat terpotongnya jaringan oleh benda yang tajam (Partogi, 2008). 
Luka bakar telah diketahui dapat disembuhkan dengan pemberian terapi salep kitosan. Menurut penelitian yang dilakukan Wardono, dkk (2012), salep kitosan dengan persentase 2,5\% efektif dapat mempercepat dan meningkatkan penyembuhan dari luka bakar kimia karena kitosan memiliki kemampuan memacu jalur-jalur penyembuhan luka bakar seperti menetralkan asam sulfat sebagai zat iritatif luka bakar, kitosan dapat memblok akhiran syaraf sehingga mengurangi rasa nyeri, kitosan sebagai aktifator makrofag, menstimulasi proliferasi sel dan menghambat pertumbuhan bakteri.

Penyembuhan luka merupakan proses dinamik dan kompleks yang dapat menghasilkan pemulihan bagi jaringan yang mengalami perlukaan sehingga terbentuk integritas dan perbaikan kembali fungsi jaringan yang mengalami perlukaan (Kalangi, 2013). Proses penyembuhan luka terdiri dari empat fase yaitu hemostasis, inflamasi akut, proliferasi (granulasi), dan remodeling (maturasi dan kontraksi) (McGavin and James, 2016). Salah satu peran krusial dalam penyembuhan luka yaitu proses angiogenesis yang berperan membentuk pembuluh darah baru dari pembuluh darah yang telah ada sebelumnya dengan cara mengelilingi bekuan darah dan membentuk ke dalam mikrovaskuler di sepanjang jaringan granulasi (Honnegowda, et al., 2015).
Penyembuhan luka dapat dilakukan dengan penambahan antiseptik pada daerah luka, zat kimia yang biasa digunakan yaitu povidone iodine yang dapat menghambat pertumbuhan kuman, namun povidone iodine $10 \%$ dapat menghambat pertumbuhan fibroblas (Putri, dkk., 2015). Kitosan sebagai alternatif obat untuk penyembuhan luka yang tidak menimbulkan efek samping perlu diteliti lebih lanjut. Sehingga perlu dilakukan penelitian untuk mengetahui pengaruh salep kitosan pada luka eksisi dengan pengamatan secara mikroskopis untuk mengetahui gambaran histopatologi proses penyembuhan luka eksisi pada kulit melalui pengamatan pada angiogenesis.

\section{METODE PENELITIAN}

\section{Alat dan Bahan}

Bahan yang digunakan dalam penelitian ini yaitu 20 ekor tikus putih (Rattus norvegicus) galur wistar dengan umur 12 minggu dengan berat \pm 150 gram, kulit udang yang berasal dari PT. Istana Cipta Sembada Banyuwangi, povidone iodine $10 \%$ (Betadine ${ }^{\circledR}$ ), $\mathrm{NaCl}$ fisiologis, Xylazine, Ketamin, Sabun Cair, Alkohol 70, makanan hewan coba berupa pellet merk All feed-4, air minum, kapas steril, larutan $\mathrm{NaOH} 6 \%$, larutan $\mathrm{NaOH} 50 \%$, larutan $\mathrm{HCl} 1,1 \mathrm{~N}$, aquades, Adeps Lanae dan Vaselin Flavum.

Alat yang digunakan dalam penelitian ini yaitu timbangan digital, 
oven, beaker glass $500 \mathrm{ml}$, gelas ukur $500 \mathrm{ml}$, hotplate dan stirrer (IKA® CMAG HS 7), mortar, stamper, sudip, spatel, pot salep, penimbang berat badan tikus, kandang box tikus, alas kandang menggunakan serbuk kayu steril, tempat makan dan minum, sarung tangan kain, glove karet, blade no. 11, blade no. 20, scalpel no.3dan no. 4 , spuit $1 \mathrm{ml}$, jarum suntik tuberculin, pinset anatomis, penggaris, kasa steril, alat pencukur bulu, under pads (sensipads),cotton bud, gunting dan mikroskop trinokuler.

\section{Perlakuan}

Penelitian ini menggunakan Rancangan Acak Lengkap (RAL) yang terdiri dari lima kelompok perlakuan yaitu yaitu $\mathrm{K}+$ luka eksisi dengan pemberian povidone iodine, $\mathrm{K}$ - luka eksisi dengan pemberian salep tanpa kitosan, P1 luka eksisi dengan pemberian salep kitosan 1,5\%, P2 luka eksisi dengan pemberian salep 2,5\% dan P3 luka eksisi dengan pemberian salep kitosan $5 \%$. Setiap kelompok perlakuan terdiri dari empat ekor tikus. Terapi dilakukan sehari sekali selama tujuh hari.

\section{Analisis Data}

Analisis data yang digunakan terhadap perhitungan jumlah pembuluh darah pada sediaan preparat histopatologi ini yaitu uji one way anova dan dilanjutkan dengan uji LSD dengan derajat kemaknaan $\mathrm{p}<0,05$.
Berdasarkan penelitian yang telah dilakukan secara mikroskopis terlihat gambaran histopatologi yang telah diamati secara kuantitatif memiliki perbedaan hasil yang signifikan. Gambaran histopatologi tersebut kemudian dihitung secara kuantitatif jumlah pembuluh darah baru dan dirata-rata. Tabel 1 menunjukkan mengenai hasil rata-rata dari setiap kelompok perlakuan. Hasil dari analisis data tersebut diketahui bahwa P1 dan P2 memiliki perbedaan nilai rata-rata yang signifikan dibandingkan dengan kelompok perlakuan lain yaitu $\mathrm{K}(+), \mathrm{K}(-)$ dan $\mathrm{P}$ 3. Gambar 1 menunjukkan gambaran histopatologi dari kelompok $\mathrm{K}+$ dan K-. Gambar histopatologi kelompok $\mathrm{K}+$ memiliki jumlah pembuluh darah baru lebih banyak dari K-. Jumlah pembuluh darah baru pada gambar $\mathrm{K}+$ yaitu 12 sedangkan pada gambar K- yaitu 7. Gambar 2 menunjukkan gambar histopatologi dari kelompok P1 dan P2. Gambar histopatologi kelompok P1 memiliki jumlah pembuluh darah baru yang lebih banyak dari P2. Jumlah pembuluh darah baru pada gambar P1 yaitu 27 sedangkan pada P2 yaitu 19. Gambar 3 menunjukkan gambaran histopatologi dari kelompok P3. Gambar histopatologi kelompok P3 memiliki jumlah pembuluh darah baru yang lebih sedikit dari kelompok perlakuan lain yaitu 6 .

\section{HASIL}


Tabel 1. Rata-rata jumlah pembuluh darah baru pada setiap kelompok perlakuan

\begin{tabular}{cc}
\hline Perlakuan & $\begin{array}{c}\text { Rata-rata } \pm \\
\text { Simpangan baku }\end{array}$ \\
\hline K (+) & $4,5386^{\mathrm{b}} \pm 0,71202$ \\
K (-) & $4,5275^{\mathrm{b}} \pm 1,55733$ \\
P 1 & $8,1500^{\mathrm{a}} \pm 0,40620$ \\
P 2 & $7,5100^{\mathrm{a}} \pm 0,69493$ \\
P 3 & $4,1775^{\mathrm{b}} \pm 1,22304$ \\
\hline
\end{tabular}

Keterangan. Superskrip yang berbeda pada kolom yang sama menunjukkan perbedaan yang signifikan $(\mathrm{p}<0.05)$

\section{PEMBAHASAN}

Jumlah pembuluh darah baru pada kelompok $\mathrm{K}(+)$ povidone iodine pada penelitian ini memiliki rata-rata yang lebih tinggi dari $\mathrm{K}(-)$ basis salep dan P3 salep kitosan 5\% tetapi lebih rendah dari P1 salep kitosan 1,5\% dan P2 salep kitosan 2,5\%. Hasil tersebut kemungkinan disebabkan disebabkan karena povidone iodine bersifat sebagai antiseptik dalam luka, sehingga luka tetap terjaga dari adanya infeksi mikroba. Hal ini sesuai dengan pernyataan bahwa povidone iodine merupakan obat kimia yang memiliki efek antimikroba dan kandungan molekul fosfolipid pada povidone iodine dapat mengkoordinasi migrasi dari sel endotel dan otot polos vaskuler yang akhirnya menginduksi angiogenesis

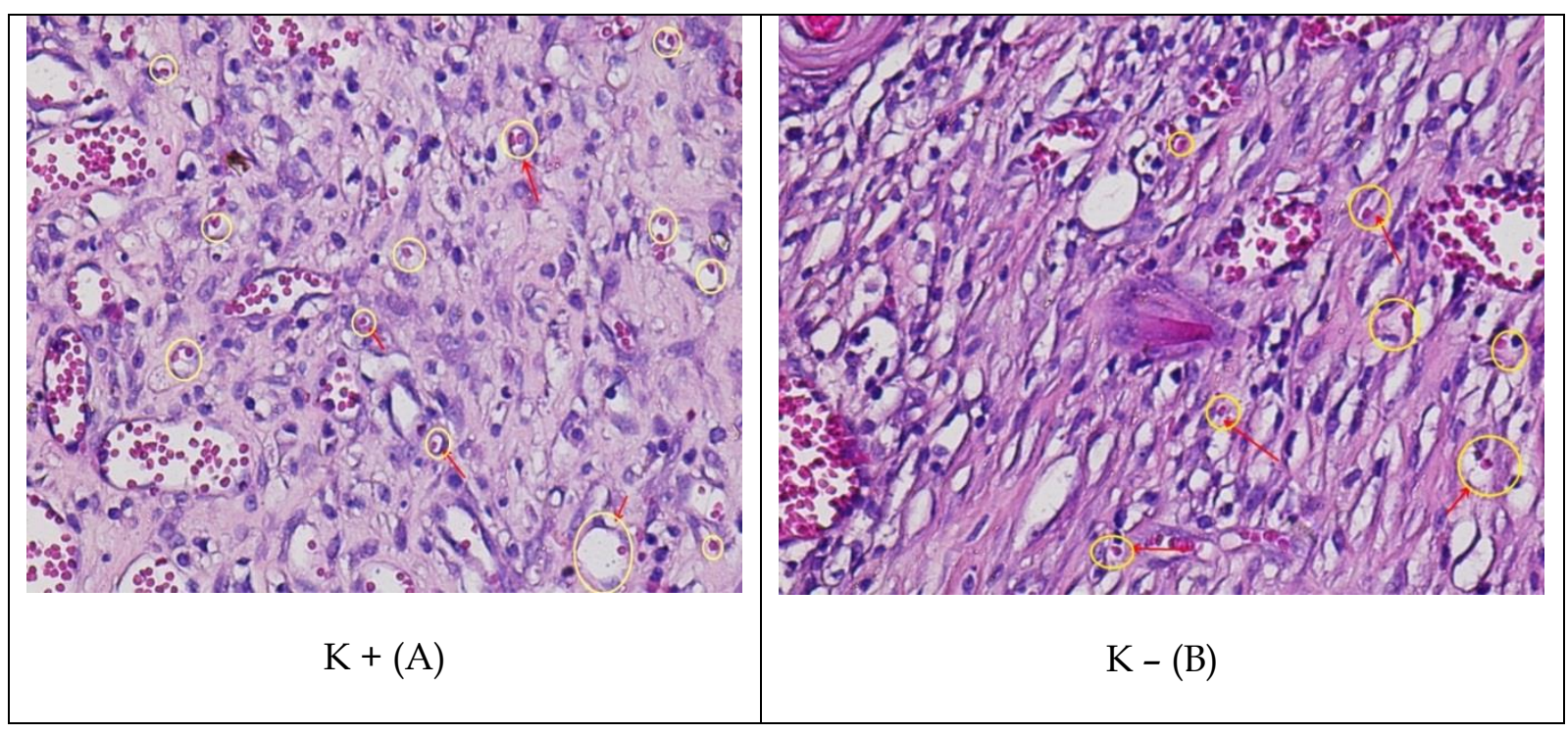

Gambar 1 Gambaran histopatologi K+ (A) dan K- (B) menggunakan mikroskop trinokuler Nikon Eclipse E200, perbesaran 400 x dengan pewarnaan $\mathrm{HE}$ 


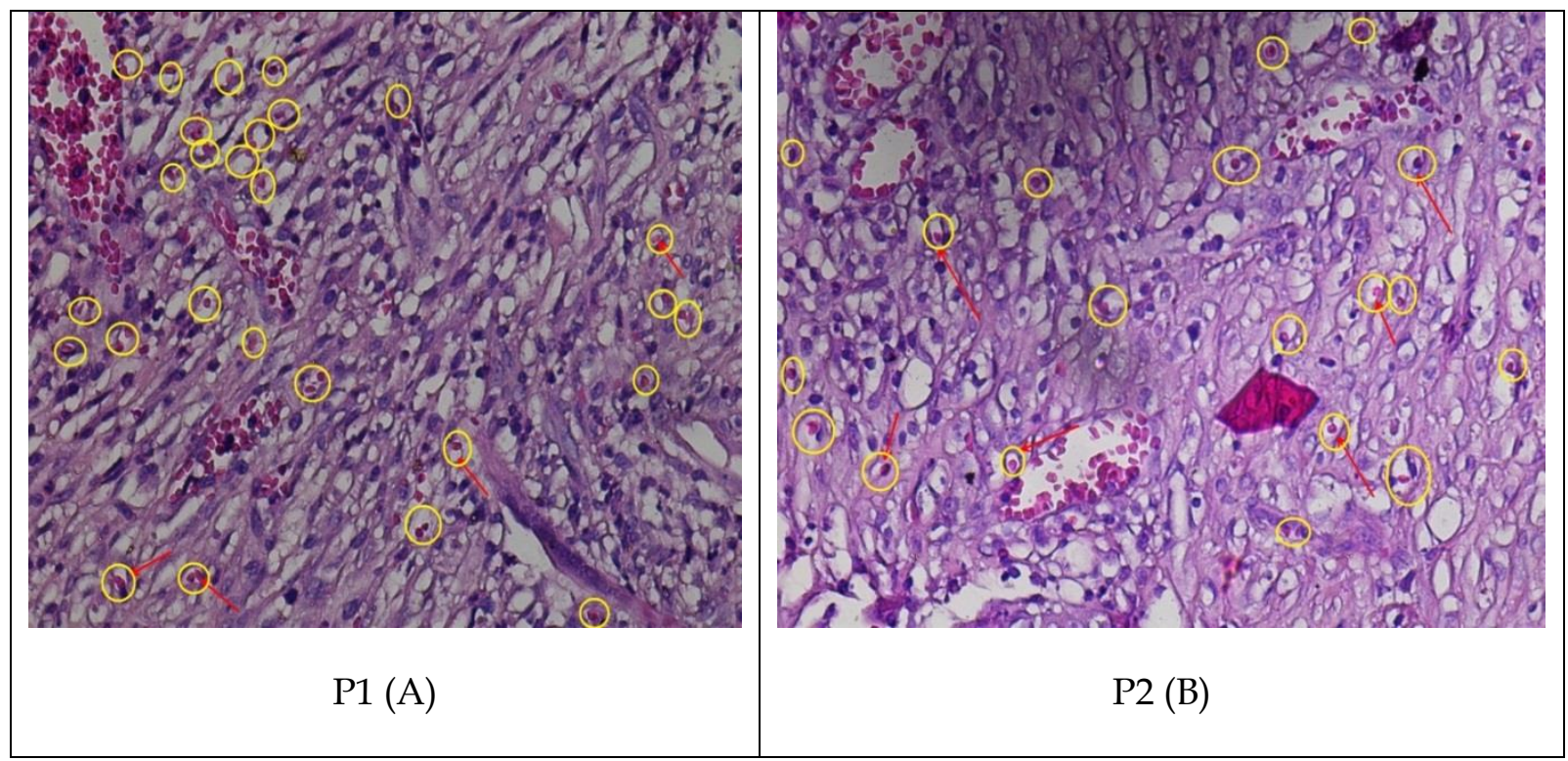

Gambar 2. Gambaran histopatologi P1 (A) dan P2 (B) menggunakan mikroskop trinokuler

Nikon Eclipse E200, perbesaran 400 x dengan pewarnaan HE.

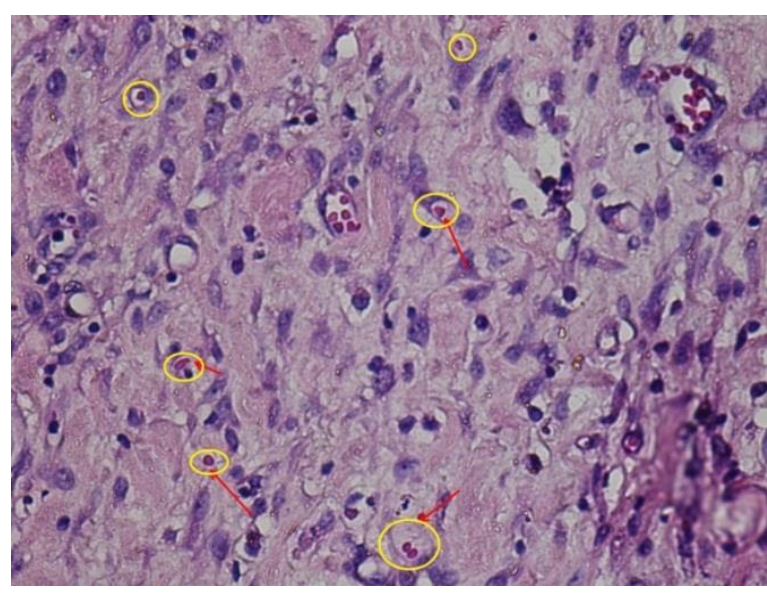

Gambar 3. Gambaran histopatologi P3 menggunakan mikroskop trinokuler Nikon Eclipse E200, perbesaran $400 \times$ dengan pewarnaan HE.
(Atik dan Januarsih, 2009).

Jumlah pembuluh darah baru pada kelompok $\mathrm{K}(-)$ basis salep (vaseline flavum dan adeps lanae) pada penelitian ini memiliki hasil rata-rata yang lebih rendah dari $\mathrm{K}(+)$ povidone iodine, P1 dan P2 namun lebih tinggi dari P3. Pemberian basis salep tanpa kitosan pada penelitian ini digunakan untuk memastikan bahwa bahan kitosan yang memberikan efek penyembuhan luka. Penggunaan basis salep tanpa adanya bahan aktif kitosan digunakan sebagai bahan penutup luka untuk menghindari infeksi dari lingkungan luar dan menjaga kelembapan kulit. Hal ini sesuai bahwa basis salep yang digunakan yaitu vaseline flavum merupakan senyawa yang bersifat hidrokarbon yang tidak mudah hilang ketika terkena air. 
Vaseline flavum juga bersifat sebagai emolient dan moisturizer yang dapat mempertahankan kelembapan kulit (Handayani, dkk., 2016). Vaseline memiliki kemampuan menyerap air yang cukup kecil yaitu 5\%, untuk menaikkan kemampuan menyerap air dapat ditambahkan kholesterol. Adeps lanae mengandung kholesterol tinggi dalam bentuk ester dan alkohol, sehingga dapat mengabsorbsi air (Anief, 1997). Proses angiogenesis yang terjadi pada $\mathrm{K}(-)$ tidak setinggi $\mathrm{K}(+)$ namun tidak berbeda jauh hal ini terjadi karena angiogenesis terjadi akibat respon tubuh untuk memperbaiki kerusakan jaringan yang terjadi (self healing).

Jumlah pembuluh darah baru pada kelompok P1 (salep kitosan 1,5\%) pada penelitian ini memiliki rata-rata yang paling tinggi dibandingkan dengan kelompok perlakuan yang lainnya. Hasil tersebut terjadi karena adanya senyawa aktif dari kitosan yang dapat mempercepat proses penyembuhan luka. Hal ini sesuai dengan pernyataan pada penelitian sebelumnya bahwa kitosan memiliki bahan aktif yaitu N-acetylglukosamine yang dapat berikatan denga FGF yang menstimulasi angiogenesis. Monomer $\mathrm{N}$-acetylglukosamine akan berikatan dengan reseptor utama pada makrofag untuk kitosan yaitu mannosa reseptor, selanjutnya kitosan diinternalisasi oleh sel makrofag dan memicu migrasi dan proliferasi sel makrofag. Sel makrofag yang teraktivasi akan meningkatkan aktivitas metabolik seperti sekresi VEGF, FGF, TGF dan angiopoitin yang akan memicu terbentuknya pembuluh darah baru (Puspita, dkk., 2015). Kitosan juga memiliki daya antiinfeksi yaitu kemampuan anti bakteria dan anti fungal, selain itu juga mampu menghentikan pendarahan pada fase awal luka (Wardono, dkk., 2012). Basis salep berlemak yaitu campuran vaselin flavum dan adeps lanae yang ditambahkan dengan kitosan juga berguna menarik lebih banyak air sehingga luka cepat kering, tidak membusuk dan menutupi luka (Anief, 1997).

Jumlah pembuluh darah baru pada kelompok P2 (salep kitosan 2,5\%) pada penelitian ini memiliki rata-rata yang lebih rendah dari P1 tetapi lebih tinggi dibandingkan dengan kelompok perlakuan yang lainnya. Hasil rata-rata pembuluh darah baru P2 terhadap P1 juga tidak memiliki perbedaan yang terlalu besar. Hasil ini disebabkan jumlah konsentrasi kitosan yang semakin tinggi memungkinkan adanya perbedaan waktu dalam proses penyembuhan luka yang dapat dilihat dari proses angiogenesis. Kelompok perlakuan P1 dan P2 memiliki rata-rata jumlah pembuluh darah baru yang lebih tinggi dari kelompok lain sesuai hasil analisis data yang membuktikan bahwa dapat mempercepat proses penyembuhan luka.

Jumlah pembuluh darah baru pada kelompok P3 (salep kitosan 5\%) pada penelitian ini memiliki rata-rata 
yang paling rendah dari semua kelompok perlakuan. Jumlah basis salep yang digunakan pada salep kitosan 5\% kemungkinan belum cukup untuk membuat luka tetap lembap karena konsentrasi kitosan lebih pekat. Jumlah basis salep yang sedikit ini memungkinkan kemampuan dalam menciptakan lingkungan luka yang lembap juga berkurang (Rahma, 2014). Basis salep yang terdiri dari vaseline flavum dan adeps lanae berfungsi sebagai penutup oklusif kulit sehingga dapat menghidrasi luka, meningkatkan daya absorbsi obat dan membuat kondisi lembap. Perawatan luka yang lembap dapat mencegah dehidrasi kulit, mempercepat pemecahan jaringan nekrotik, fase inflamasi, kontraksi luka, re-epitel, mengurangi resiko infeksi dan mempercepat angiogenesis (Andrie dan Dies, 2017). Kadar konsentrasi kitosan yang terlalu tinggi yaitu 5\% juga memungkinkan kurang mampu untuk memacu berbagai proses dalam jalur penyembuhan luka. Sesuai penelitian sebelumnya bahwa kitosan yang memiliki konsentrasi lebih kecil maka akan semakin memiliki kemampuan daya sembuh dalam memacu jalur-jalur penyembuhan. Dosis kitosan yang telah diteliti adalah dalam rentang 0,1 - $5 \%$ untuk dosis topikal (Wardono, dkk.,2012).

\section{KESIMPULAN}

Berdasarkan penelitian yang
telah dilakukan salep kitosan efektif dalam meningkatkan jumlah pembuluh darah baru. Salep kitosan dengan konsentrasi 1,5\% memberikan hasil rata-rata jumlah pembuluh darah baru yang lebih tinggi dari kelompok lainnya.

\section{UCAPAN TERIMAKASIH}

Peneliti mengucapkan terimakasih kepada Universitas Airlangga PSDKU Banyuwangi atas izin dan fasilitas yang telah diberikan untuk melaksanakan penelitian.

\section{DAFTAR PUSTAKA}

Andrie, M., dan Dies, S. 2017. Efektivitas Sediaan Salep yang Mengandung Ekstrak Ikan Gabus (Channa striata) pada Proses Penyembuhan Luka Akut Stadium II Terbuka pada Tikus Jantan Galur Wistar. Pontiana. Fakultas Kedokteran Universitas Tanjungpura.

Anief, M.1997. Ilmu Meracik Obat. Gajah Mada University Press. Jogjakarta. 10-17

Arun, M., Sardana, S., Pandey, A. 2013. International Journal of Pharmacy and Pharmaceutical Science.

Atik, N., Januarsih, I. A. R. 2009. Perbedaan Efek Pemberian Topikal Gel Lidah Buaya (Aloe vera L.) dengan Solusio Povidone iodine Terhadap Penyembuhan Luka Sayat pada Kulit Mencit. 
Bandung. Fakultas Kedokteran Universitas Padjajaran Bandung.

Dompeipen, E. J., Kaimudin, M., dan Dewa, R. P. 2016. Isolasi Kitin Dan Kitosan Dari Limbah Kulit Udang. Majalah Biam, 12(1), 32-39.

Handayani, F., Reksi S., dan Henriko N.K. 2016. Aktivitas Etanol Biji Pinang (Areca catecu L.) terhadap Penyembuhan Luka Bakar pada Kulit Punggung Mencit Jantan (Mus musculus). Jurnal Ilmiah Manuntung. 2(2): 158.

Honnegowda, T. M., Kumar, P., Udupa, E. G. P., Kumar, S., Kumar, U., dan Rao, P. 2015. Role of angiogenesis and angiogenic factors in acute and chronic wound healing. Plast Aesthet Res, 2, 243-249.

Kalangi, S. J. 2013. Histofisiologi kulit. Jurnal Biomedik, 5(3).

McGavin, M. D., dan Zachary, J. F. 2016. Pathologic Basis of Veterinary Disease. Elsevier Health Sciences.

Partogi, Donna. 2008. Teknik Eksisi. Departemen Ilmu Kesehatan Kulit dan Kelamin FK Universitas Sumatera Utara/ RSUP H. Adam Malik/ RS. Dr. Pirngadi Medan.

Puspita , Bella, Sagita., Sularsih., Dian,

W, D. 2015. Perbedaan Pengaruh Pemberian Kitosan Berat Molekul Tinggi dan Rendah terhadap Jumlah Pembuluh Darah pada Proses Penyembuhan Luka Pencabutan Gigi. Universitas Hang Tuah. Surabaya.
Putri, S., Djamal, A., Rahmatini, R., dan Ilmiawati, C. 2015. Perbandingan Daya Hambat Larutan Antiseptik Povidone iodine dengan Ekstrak Daun Sirih terhadap Candida albicans secara In Vitro. Jurnal Kesehatan Andalas, 4(3).

Rahma, F. N. 2014. Pengaruh Pemberian Salep Ekstrak Daun Binahong (Ianredera cordifolia (Tenore) Steenis) Terhadap ReEpitelisasi pada Luka Bakar Tikus Sprague dawley [Skripsi]. Jakarta. Fakultas Kedokteran dan Ilmu Kesehatan Universitas Islam Negeri Syarif Hidayatullah.

Rairisti, A. 2014. Uji Aktivitas Ekstrak Etanol Biji Pinang (Areca Catechu L.) Terhadap Penyembuhan Luka Sayat pada Tikus Putih (Rattus Norvegicus) Jantan Galur Wistar. Jurnal Mahasiswa PSPD FK Universitas Tanjungpura, 1(1).

Sastrawan, N.K.L., Anak, A. G. J. W., I. Ketut. A. D., L. M. Sudimartini. 2016. Perbandingan Kecepatan Kesembuhan Luka Insisi yang Diberi Amoksisilin-Deksametason dan Amoksisilin-Asam Mefenamat pada Tikus Putih ( Rattus norvegicus ). Universitas Udayana.

Tekelioglu, B. K., Celik, M., dan Kucukgulmez, A. Canine Extremity Wound Treatment with Kitosan Extracted from Shrimp Shells: A Case Report.

Wardono, A., Barii, H, P., Rizqi, A, J, H., Sri, T. 2012. Pengaruh Kitosan 
Dayanti et al. MKH (2021). 60-69

DOI: $10.20473 / \mathrm{mkh} . v 32 i 2.2021 .60-69$

$\begin{array}{lrr}\text { Secara Topikal } & \text { Terhadap } \\ \text { Penyembuhan Luka } & \text { Bakar } \\ \text { Kimiawi pada Kulit Tikus } & \text { Putih } \\ \text { (Rattus Novergicus). } & \text { Program }\end{array}$

Sarjana Fakultas Kedokteran dan

Ilmu Kesehatan. Universitas

Muhammadiyah. Yogyakarta. 